\title{
Preliminary studies of the dynamic stiffness modules of soil samples from the Solvay Sodium Plant waste landfill in Krakow
}

\author{
Elżbieta Pilecka, ${ }^{1, *}$, Jakub Zięba ${ }^{1}$ \\ ${ }^{1}$ Politechnika Krakowska, Instytut Mechaniki Budowli, 31-155 Kraków, Polska
}

\begin{abstract}
The article presents the results of laboratory tests for determining the dynamic modules of the elasticity $\mathrm{M}$ and the shear $\mathrm{G}$, for soil samples from the landfill of the closed Solvay Sodium Plant in Krakow. The tests were performed using a triaxial apparatus equipped with "bender" piezoelements. The samples subjected to these tests were taken from two boreholes, located in the area known as the "white seas", whose formation is the result of Solvay Plant activity throughout the 20th century. The location of the test holes was planned at the place in which a road known as the" Łagiewnicka route " was planned. Studies on soil stiffness were also conducted as part of the one of the dissertation from 2008 to 2010 in the Cracow University of Technology. The results of these tests and the results of the laboratory tests that are presented in the article will be used in the designing of a computer model. This model is intended to help in assessing the dynamic impact of motor vehicle traffic on the planned Łagiewnicka route on the structure of the existing buildings located in the former Solvay Plant.
\end{abstract}

\section{Introduction}

During 2008-2011 numerous studies were conducted for the construction of the John Paul II Centre in Krakow to determine geotechnical conditions and construction substrate stiffness in the "white seas" waste landfill area of the former Solvay Sodium Plant in Krakow-Łagiewniki. The purpose of this study was to determine the pile carrying capacity in the anthropogenic soil, which until now, according to the norm PN-83 / B-02482, could not have been used for a structure's foundation. The following studies were conducted by several research units, including the Cracow University of Technology, Polish Academy of Sciences, and other specialist firms such as Geoteko from Warsaw. The results of the tests were finally verified through initial execution and then by testing the bearing capacity of 9 test piles buried in the ground. The results of these studies were the subject of the dissertation, "Analysis of foundation piles carrying capacity based on field surveys made by static probe" [2]. Due to the planned road construction, which was partially located in the "white seas" area of Łagiewnicka route, a typical behaviour was observed in the substrate stiffness conditions. The studies connected with the determination of dynamic parameters,

* Corresponding author: epilecka@pk.edu.pl 
and the archival research of the foundation of the John Paul II Centre in Łagiewniki will allow the building of a numerical model, which will be used to analyse the impact of traffic load on the existing buildings in the John Paul II Centre in Cracow.

\section{Location and geological engineering conditions}

The soil samples that were studied were taken with the permission of the John Paul II Centre. The Sampling points were marked on the satellite image, where the course of Łagiewniki route is shown (fig. 1).

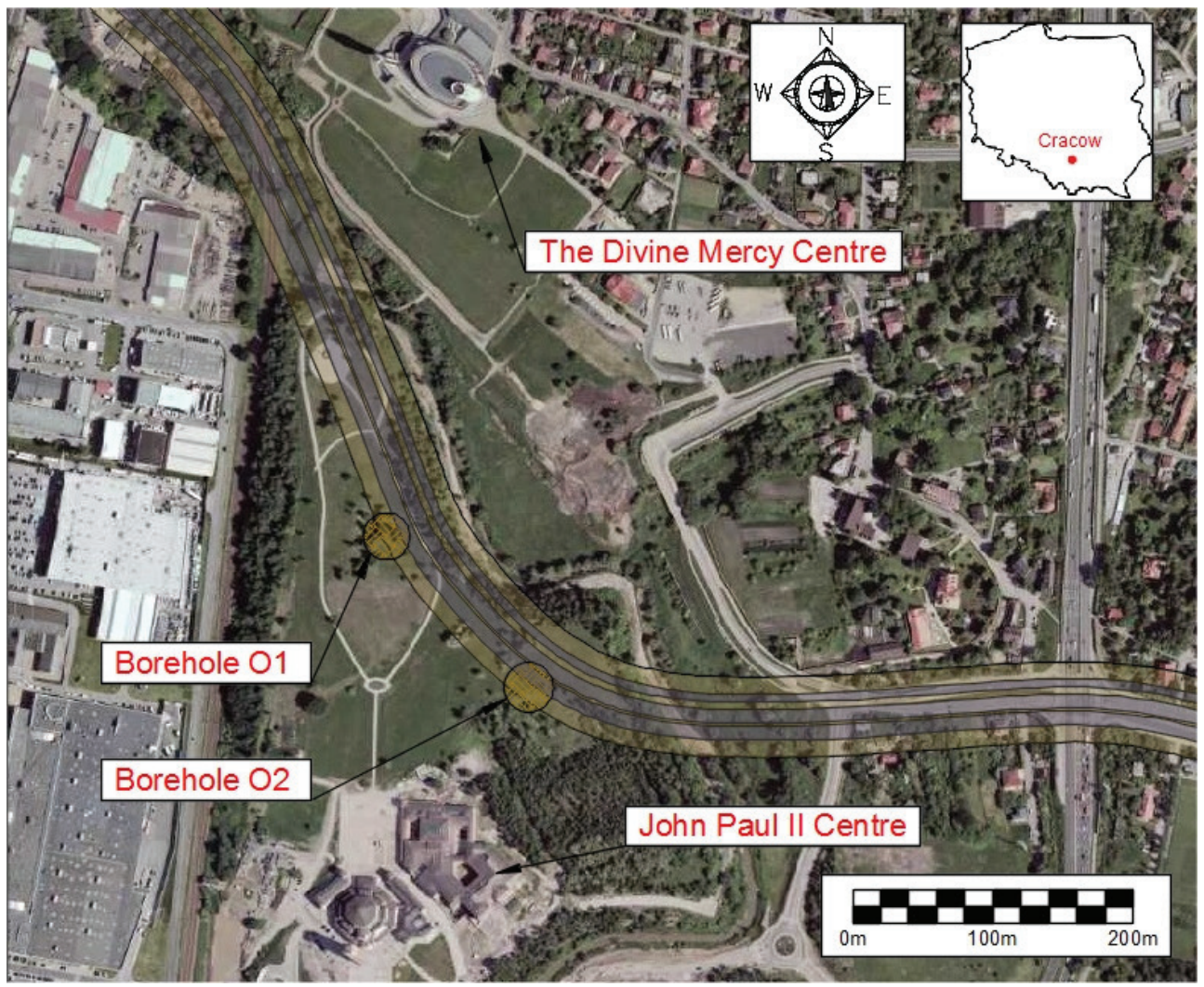

Fig. 1. Location of the "Lagiewnicka route" course in the area of Solvay Sodium Plant landfill, also indicating the location of boreholes $\mathrm{O} 1$ and $\mathrm{O} 2[10,11]$.

The waste from the Solvay Sodium Plant in Krakow was deposited on the ground. The geological structure of the studied area is typical of that of Krakow territory. There are quaternary soils in the substrate (sands and gravels; alternating with cohesive soils, mainly with silts), which lie directly on the tertiary structures, represented by the Miocene clay. The factory produced sodium carbonate $(\mathrm{Na} 2 \mathrm{CO} 3)$ since 1906 As a result of the (chemical or this) production, the studied waste was generated. This waste developed in the form of a slurry and was entirely deposited in sedimentation tanks. These tanks (fifteen of them) occupied a total area of over 30 hectares. The stored waste stood at a height of nearly 20 meters.

In the 1990s, on the basis of hydrogeological and hydrotechnical studies, the environmental effect of the waste from the Solvay Plants was analysed [3], and then the reclamation of this area was decided. The designated plan [4] and further development 
plans in the area of Łagiewniki forced the necessity of analysing the soil substrate and evaluating its suitability for construction purposes.

According to the plan of the Łagiewnicka route in Krakow [5], three geotechnical boreholes were made, which confirmed the occurrence of anthropogenic soils in the road subgrade. It has been found that the surface layer consists of production waste in a different state and degree of consolidation. On the basis of macroscopic examination of the test holes, the presence of calcium carbonate, sodium carbonate, and calcium sulphate was confirmed.

\section{Material and methodology}

The soil for the laboratory tests was taken from the two test boreholes, $\mathrm{O} 1$ and $\mathrm{O} 2$. In both boreholes below the gravel layer, the presence of anthropogenic soils was observed, mainly in the state between a semi-compact and a plastic one. The main element of the anthropogenic soil is calcium carbonate $(\mathrm{CaCO} 3)$, which occurs together with silicon oxides (SiSO2) and other substances (i.e. P2O5, CaSO4, $\mathrm{MgSO} 4, \mathrm{BaSO} 4, \mathrm{NaCl}, \mathrm{CaCl} 2$ [1]).

No water levels have been found in the boreholes. The water content in the samples varied and ranged in different degrees of saturation. Moreover, locally, there are soft plastic lime mixtures with gravel and slag with thickened (crystalized and solidified) lime. An observed characteristic phenomenon was the increased hardness of the surface layer (0.5-1.2m), composed mainly of dried, hard lime.

After being transported to the laboratory, the soil was stored at a temperature of $5^{\circ} \mathrm{C}$ until sample formation and testing. Due to the high variability of soil moisture in test borehole $\mathrm{O} 1$, samples with a natural water content measurement were taken and molded after being completely dried. The dry samples were condensed to constant volume density of all tested samples. The compaction was also due to the fact that the sample after drying revealed the porous structure and simultaneously the dried sample was crushed.

The tests were performed using a triaxial apparatus, which is equipped with a wave generator and caps attached to the tested sample. This apparatus holds the ability to generate $\mathrm{S}$-wave and $\mathrm{P}$-wave. The waves are then excited in a piezoelectric bender elements device, and they deform due to a change in tension. Using the triaxial apparatus, velocity wave measurements were made during isotropic tension. The soil strain corresponds to the range of $10^{-4} \div 10^{-5} \%$ [6].

The test equipment used in this study is shown in figure 2. A detailed description of the triaxial apparatus is presented in works [7, 8].

The result of the test is a graph of the recorded voltage on the piezoelectric bender elements, which is the basis for determining the wave velocity. On the basis of the P-wave propagation time, the value of the modulus of elasticity $M$ can be calculated from the following equation:

$$
\mathrm{M}=\rho \mathrm{V}_{\mathrm{p}}^{2}
$$

where:

$\rho$ - bulk density,

$\mathrm{Vp}-\mathrm{P}$-wave velocity.

The time of the wave propagation is measured by the "peak to peak" method. Cylindrical samples, $5 \mathrm{~cm}$ in diameter and $5 \mathrm{~cm}$ high, were used. Before starting the velocity measurement, delay time and polarity were checked. For a test sample, a series of tests was performed to determine the correct amplitude and frequency of the input signal for the shear and compression waves [9]. All tests were performed using a sinusoidal wave, 
generated with time intervals of 15 seconds. This time was determined on the basis of the total time of signal suppression and the time necessary for registering the reply. The registered signal was filtered into a continuous function to better evaluate wave transition time. For this purpose, a moving average method was used with an eight-point window. For each sample, twenty designations were made. In addition, for comparison purposes and the possibility of modelling the medium in subsequent research, measurements of the S-wave velocity were carried out to determine the dynamic modulus of rigidity G:

$$
\mathrm{G}=\rho \mathrm{V}_{\mathrm{s}}^{2}
$$

where: Vs - S-wave velocity.

Assuming the elastic model of the analysed soil and knowledge of shear and pressure wave velocity, it is also possible to determine the dynamic Poisson's ratio $\square$, according to the formula.

$$
v=\frac{\frac{1}{2}\left(\frac{V_{P}}{V_{S}}\right)^{2}-1}{\left(\frac{V_{P}}{V_{S}}\right)^{2}-1}[-]
$$

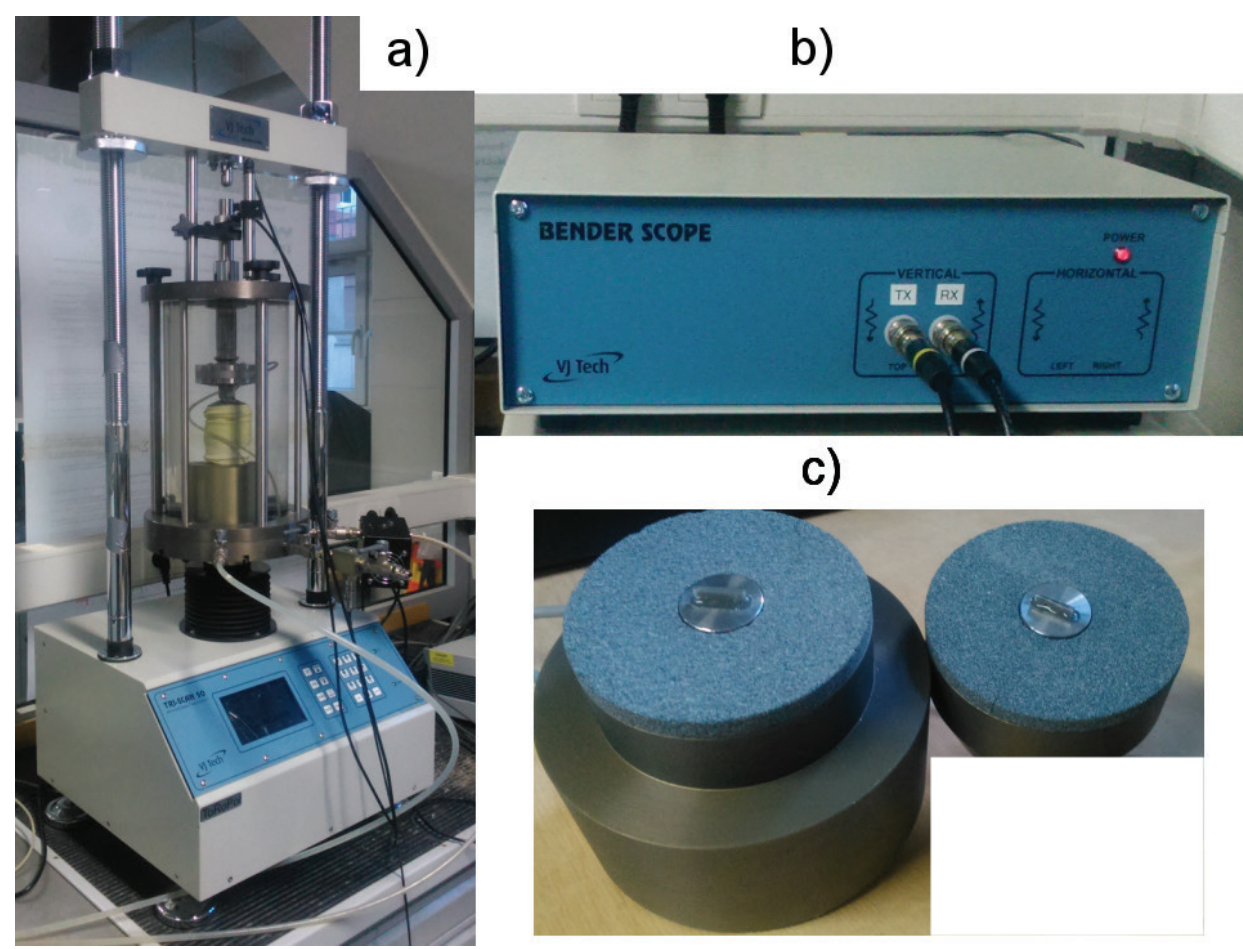

Fig. 2. Test equipment a) triaxial apparatus b) waveform generator c) bender element.

At the beginning, series of sample tests were conducted for identification the best signal in the receiver, which allows a precise determination of wave time [9].

The tests of the natural moisture samples were carried out for the $\mathrm{S}$-wave at a $10 \mathrm{~V}$ amplitude and a signal frequency in the transmitter of $1 \mathrm{kHz}$ and for P-wave the amplitude was $12 \mathrm{~V}$ and frequency $5 \mathrm{kHz}$. Furthermore, the tests of the natural, dried sample were 
carried out for the S-wave for $10 \mathrm{~V}$ amplitude and the frequency of $10 \mathrm{kHz}$, for $\mathrm{P}$-wave the amplitude was $12 \mathrm{~V}$ and frequency $5 \mathrm{kHz}$.

The test time was adjusted in order to reach the peak and to mute the signal in the receiver. The signal was filtered to a continuous function, in order to obtain a more precise evaluation of the wave propagation time. Twenty tests were performed for each sample. The applied filtering method is a moving average method called the "running mean smoother," which uses an eight-point window.

\section{Results and analysis}

The measurement results for the natural moisture sample are shown in figures 3 and 4 , and the measurement results for the dry sample are shown in figures 5 and 6 . The measured and calculated parameters are shown in table 1 for $\mathrm{P}$-wave and in table 2 for $\mathrm{S}$-wave.

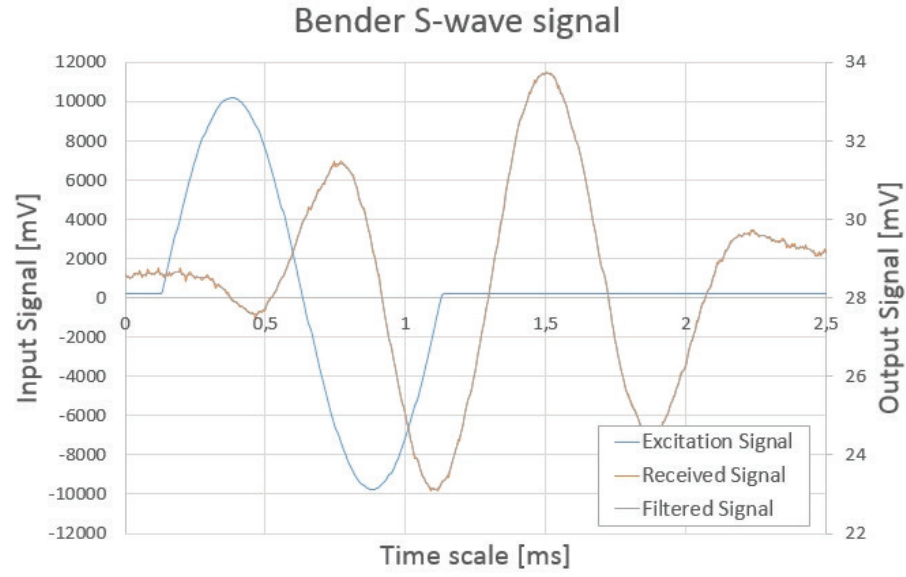

Fig. 3. The S-wave excitation and received signal of natural water content sample.

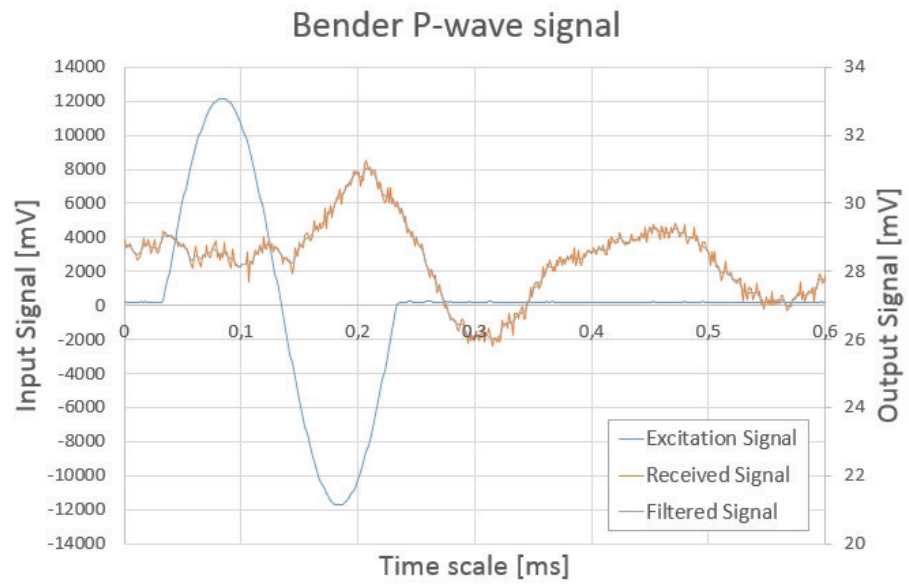

Fig. 4. The P-wave excitation and received signal of natural water content sample. 


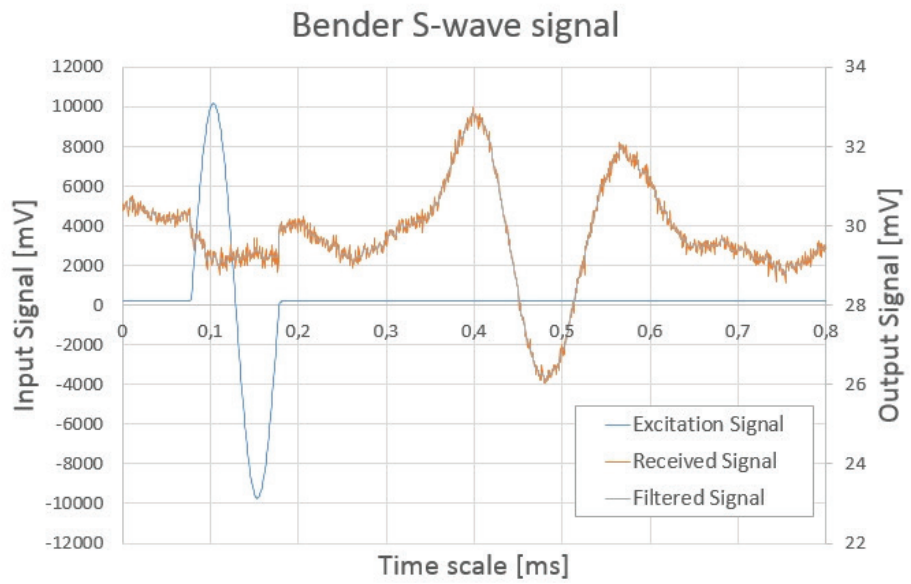

Fig. 5. The S-wave excitation and received signal of a dry sample.

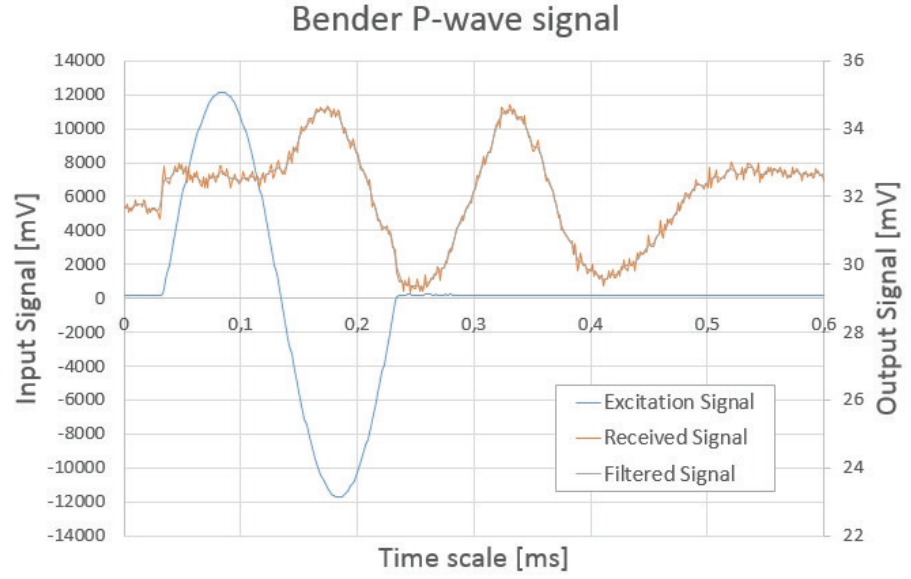

Fig. 6. The P-wave excitation and received signal of a dry sample.

Table 1. The average values of the parameters of the tested samples for P-wave test.

\begin{tabular}{|c|c|c|c|}
\hline Sample & $\begin{array}{c}\text { Bulk density } \\
{[\mathrm{kg} / \mathrm{m} 3]}\end{array}$ & $\begin{array}{c}\text { P-wave velocity } \\
{[\mathrm{m} / \mathrm{s}]}\end{array}$ & $\begin{array}{c}\text { M modulus } \\
{[\mathrm{MPa}]}\end{array}$ \\
\hline Natural water content & 1780 & 221 & 87 \\
\hline Dry sample & 1780 & 316 & 178 \\
\hline
\end{tabular}

Table 2. The average values of the parameters of the tested samples for S-wave test.

\begin{tabular}{|c|c|c|c|}
\hline Sample & $\begin{array}{c}\text { Bulk density } \\
{[\mathrm{kg} / \mathrm{m} 3]}\end{array}$ & $\begin{array}{c}\text { S-wave velocity } \\
{[\mathrm{m} / \mathrm{s}]}\end{array}$ & $\begin{array}{c}\text { G modulus } \\
{[\mathrm{MPa}]}\end{array}$ \\
\hline Natural water content & 1780 & 101 & 18 \\
\hline Dry sample & 1780 & 82 & 12 \\
\hline
\end{tabular}

For the determined P-wave, the difference in the calculated values for the dry sample and for the natural moisture sample is rather high. In the case of the S-wave, the water impact is lower. The dynamic $\mathrm{G}$ modulus of the soil samples after drying insignificantly 
decreased, which may be due to a change in the structure of the sample which, after drying, had a fine sand/dust structure.

In the case of the P-wave, a significant increase in the dynamic $\mathrm{M}$ modulus was observed after drying. It is possible that it is the result of the sample compaction after drying. Poisson's coefficient for soil samples with a natural water content was 0.37 . For dry soil sample, the coefficient was 0.46 .

\section{Conclusions}

This work presents the results of the laboratory tests of the dynamic modules of soil samples from a landfill site in the area of the closed Solvay Sodium Plant in Krakow. The results of laboratory tests, together with the results of field tests, were carried out as a part of the diagnosis of the ground for the investment of the John Paul II Centre in Łagiewniki, Krakow. They will be used to build a numerical model which will allow to analyse the impact of traffic load on the buildings of the John Paul II Centre.

The study area is characterized by a high variability of the subsoil state, and, in particular, its consistency. Due to the possibility of using the subsoil as a foundation for the future road investment, extensive tests on its stiffness should be conducted. This article discusses the lab methodology for determining the stiffness of the subsoil, expressed by the dynamic modulus of elasticity $\mathrm{M}$ and rigidity $\mathrm{G}$. For this purpose, a triaxial apparatus equipped with piezoelements was used.

The preliminary results show relatively small values of the subsoil dynamic stiffness parameters. This points to the need to strengthen this subsoil for its use for construction purposes, and, in particular, for the construction of a future transportation route.

\section{References}

1. I. Krzak, Zagospodarowanie terenów poprzemystowych Krakowskich Zakładów Sodowych ,Solvay”, Problemy Ekologii Krajobrazu, Tom 17, 283-287 (2005)

2. B. Czado, Analiza nośności pali fundamentowych na podstawie polowych badań gruntów sonda statyczna, Rozprawa doktorska, Biblioteka Politechniki Krakowskiej (2014)

3. A. Ślęzak, Wptyw składowiska odpadów Krakowskich Zakładów Sodowych na wody [In]: Przewodnik III Konferencji Sozologicznej PTG. Sozologia na obszarze antropopresji - przykład Kraków (Wyd. AGH, Kraków, 1993)

4. Biuro Rozwoju Krakowa, Miejscowy plan zagospodarowania przestrzennego terenów Krakowskich Zakładów Sodowych „Solvay” $w$ likwidacji, $w$ rejonie ulic: Zakopiańskiej, Myślenickiej i Podmokłej (Kraków, 1994)

5. Program Funkcjonalno-Użytkowy „Budowa Trasy Łagiewnickiej w Krakowie od skrzyżowania z ul. Grota-Roweckiego do skrzyżowania z ul. Beskidzka i z ul. Halszki wraz z budowa odcinka linii tramwajowej”. Materiały przetargowe, Spółka Trasa Łagiewnicka S.A

6. T. Godlewski, T. Szczepański, Metody określania sztywności gruntów w badaniach geotechnicznych (Wydawnictwo Instytut Techniki Budowlanej, Warszawa, 2015)

7. J. Zięba, D. Szwarkowski, Slope stability analysis of an open-pit mine as a prospective $S-7$ and $S$-52 road intersection, Czasopismo Techniczne (2017) (in press) 
8. J. Kogut, J. Zięba, The measurement of selected soil parameters of former open pit mine with the use of triaxial stress apparatus, Czasopismo Inżynierii Lądowej, Środowiska i Architektury 1, 64, 97-104 (2017)

9. W. Świdziński, J. Mierczyński, Investigations of elastic response of non-cohesive soils by seismic waves, Czasopismo Techniczne. Środowisko 107, 1-Ś, 63-82 (2010)

10. http://trasalagiewnicka.krakow.pl/

11. http://www.geoportal.gov.pl// 